\title{
An Expanded Role for the State in Regional Land Use Control
}

\begin{abstract}
State control over land use has not achieved the "quiet revolution" predicted by Bosselman and Callies in $1971 .{ }^{1}$ Many states now play a stronger role in land use regulation, but their efforts have typically supplemented, rather than supplanted, local control. ${ }^{2}$ Cities have retained their monopoly largely because over the years local governments have developed a variety of institutions for handling land use conflicts. ${ }^{3}$ However, the efficiency of local regulation is hindered by a tendency of local officials to discount the negative impacts that land use decisions can create outside city limits. ${ }^{4}$ In California, state intervention has only partially compensated for this shortcoming. ${ }^{5}$

The California Supreme Court recognized the dilemma created by
\end{abstract}

1. F. Bosselman \& D. Callies, The Quiet Revolution in Land Use Control (1971).

The authors predicted a new, expanded role for state government:

This country is in the midst of a revolution in the way we regulate the use of our land. It

is a peaceful revolution, conducted entirely within the law. It is a quiet revolution, and

its supporters include both conservatives and liberals. It is a disorganized revolution,

with no central cadre of leaders, but it is a revolution nonetheless.

Id. at 1 .

2. In California, for example, state land use regulation has taken three different forms. First, through the Office of Planning and Research, the state carries out planning, including the formulation, evaluation, and updating of long range goals and policies for land use. CAL. Gov't CODE \& 65035 (West Supp. 1981). Second, on the coastline the state lias retained direct review authority over local land use regulations to ensure that state and regional interests in a "valuable natural resource" are protected. CAL. PUB. Res. CODE $\$ \$ 30001$ (a), 30004(b) (West 1977 \& Supp. 1981). Third, the state has expanded mandatory general plan requirements for cities and counties to promote longer-term comprehensive planning. CAL. Gov'T CODE $§ 65302$ (West Supp. 1981). These efforts have aided localities im planning, but they have not removed predomimate land use control from the local level. For an evaluation of programs in other states, see R. HEALY, LAND Use AND the States (1976).

3. See Jacobs, Local Land Use Planning and the Impacts of Emerging State Involvement, in Land USE: Planning, Politics, and Policy 6, 7 (R. Cowart ed. 1976).

4. See, e.g., Southern Burlington County NAACP v. Township of Mount Laurel, 67 N.J. 151, 171, 336 A.2d 713, 723, appeal dismissed and cert. denied, 423 U.S. 808 (1975), in which the court stated that the city had consciously pursued a course of land use regulation designed to keep local property taxes down, adding: "Almost every one [of the municipalities] acts solely in its own selfish and parochial interest and in effect builds a wall around itself to keep out those people or entities not adding favorably to the tax base . . . "See generally R. HEALY, supra note 2, at 6-I0 (interjurisdictional spillovers from development create mequitable burdens and benefits among neighboring communities); M. Levin, J. Rose \& J. SLAVet, New Approaches to State LANDUSE POLICIES 66-68 (1974) (complete delegation of land use control to local governments works to the detrinent of regional and state interests and often has unpleasant consequences for neighboring communities); D. MosKowITZ, EXCLUSIONARY ZoNING LITIGATION I1-12 (1977) (zoning machinery is narrowly focused on interests of present residents, excluding regional point of view).

5. See note 2 supra. The current emphasis of state land use efforts is not focused on the problem of extra-local impacts of local land use decisions. 
localities actimg from narrow self-interest in Associated Home Builders of the Greater Eastbay, Inc. v. City of Livermore. ${ }^{6}$ There it announced that the proper constitutional test to be applied henceforth to land use ordmances would inquire whether the ordinance reasonably related to the welfare of those whom it significantly affected. ${ }^{7}$ The decision left sonie practical questions unanswered, such as low the state's trial courts should define a relevant region ${ }^{8}$ and what standards should apply in deciding whether a party challenging a land use ordinance had inet the burden of showimg that the ordimance did not reasonably relate to the general welfare of the region. ${ }^{9}$ However, the opinion also clarified an area where the state should intervene inore aggressively in order to accomplish the Livermore court's dual objectives of requiring California cities (1) to accept their fair share of less-sought-after development such as low-mcome housing and (2) to consider the regional impact of allowing development to proceed within their jurisdictions. ${ }^{10}$

Part I of this Comment explores the ramifications of the regional impact requirements of Livermore in terıns of the strengtlis and weaknesses of local land use decisionmaking. Part II discusses two concepts that liave had limited application in California-fair slare allocations

6. 18 Cal. 3d 582, 557 P.2d 473, 135 Cal. Rptr. 41 (1976).

7. Id. at 607,557 P.2d at 487,135 Cal. Rptr. at 55 . The court reaffirmed the established constitutional principle that a local land use ordimance falls within the authority of the police power if it is reasonably related to the public welfare. However, the court expanded the notion of whose welfare must be served to imclude nonresidents of the community enacting the ordinance.

8. Id. at 609-10, 557 P.2d at 489, 135 Cal. Rptr. at 57. The court stated that the extent and bounds of the relevant region should be determmed as a question of fact by the trial court and talked only generally of Livermore and the surrounding region. Id. at $607 \mathrm{n} .24,557$ P.2d at $487 \mathrm{n}$. 24,135 Cal. Rptr. at 56 n.24. It also alluded to plaintiffs assertion that the suit was linked to an acute housing sliortage in the San Francisco Bay area. Yet the court did not explicitly state that the entire Bay area was the relevant region for the housing issue-a debatable premise for so large an area with several discrete employment centers. Presumably, the relevant region will vary according to the resource in question. Topographical conditions creating a basin might define a small relevant region within a larger area for air pollution problems. The relevant region within this same larger area might have to expand to include all the communities whose actions affect a water supply system.

9. Id. at $609-10,557$ P.2d at 489, 135 Cal. Rptr. at 57. The court stated that the plaintiff in Livermore had not met its burden because it had not introduced evidence to show the likely effcct or duration of the ordimance's restrictions on building permits or established the relationship between the probable effect of the ordinance and the housing shortage in the San Francisco Bay area. The court also chided the city for failing to support its claim that severe air pollution and imadequate public facitities made it necessary to divert new lrousing from the city. However, the court clearly placed the burden on plaintiffs as the party challenging the constitutionality of the ordinance.

10. The court's language does not indicate that its concern lay only with housing issues. The language simply states that the test will inquire whether the "ordmance reasonably relatcs to the welfare of those whoin it significantly affects." Id. at 607, 557 P.2d at 487, 135 Cal. Rptr. at 55. Therefore, Livermore-type challenges could be brought in relation to otlier issues such as open space supply or transportation capacity. An analogous challenge las been brought in Washington. See note 40 infra. 
and cumulative impact assessment-that will enable localities to incorporate a regional perspective into their land use regulations. Part 111 proposes that California develop a system of regional planning boards to apply these concepts in those vulnerable areas within the state undergoing stress from population shifts caused by development pressures or by depopulation and disinvestment. ${ }^{11}$ Because of fundimg and staffing limitations, the boards would be limited to those areas where Livermore-type challenges are most likely to arise because natural and institutional resources are scarce or threatening to becoine so. ${ }^{12}$ The regional bodies would carry out data-gathering duties typically assigned to existing regional councils. ${ }^{13}$ They also would serve as forums where elected and appointed members could make tradeoffs among

11. Vulnerable regions probably would most often encompass a metropolitan area, i.e., a core city and outlying suburbs. However, a vulnerable region might also cover a rural area where the inajor source of local employınent had left or where disaffected city residents were flocking to escape urban problems, such as crime, high rents, smog, and traffic.

12. This assumption is based on the rationale that people are unlikely to complain or to translate complaints into legal action, unless resources are becoining scarce. The inore severe the competition for scarce resources, the greater the likelihood of legal action to resolve conflict.

13. Local governments started forming regionally based councils of governments (COG's) in 1954 when many jurisdictions were making incompatible decisions leading to expensive duplication and gaps in the overall pattern of public services. Such errors were common in waste treatment and water supply. New suburban communities, hard-pressed to provide a level of services comparable to that offered in older cities, were particularly eager to take advantage of economies of scale. The idea of regional government received substantial federal support in 1965 when funds were made available to COG's for regional and state planning under amendinents to the Housing Act of 1954. See Parker, Regional Imperatives \& Managed Growth, in 3 MANAGEMENT \& CoNTROL OF GROWTH 284, 286 (1975).

California has 25 COG's that serve as clearinghouses for review of federal grant and loan applications made by communities within their regions as required by the Office of Management and Budget Circular A-95. The legislature has also delegated COG's responsibility for determining fair share allocations of low-imcone housing for communities within the region. CAL. Gov'T CODE $\S 65584$ (a) (West Supp. 1981). The state has produced soine instances of effective regional government. See, e.g., J. Pepper, AN Approach to EnVironmental Impact Evaluation of Land-Use Plans and Policies: The Tahoe Basin Planning Information System (1972); Symposium, The San Francisco Bay Area-Regional Problems and Solutions, 55 CaLIF. L. Rev. 695 (1967); Note, Regional Government for Lake Tahoe, 22 Hastings L.J. 705 (1971). But the effectiveness of COG's has more often been called into question. See, e.g., Mogulof, Regional Planning, Clearance and Evaluation: A Look at the A-95 Process, AM. Inst. Planners J., Nov., 1971 , at 418 , in which the author defines the COG's major failure as an inability to distinguish between good and bad applications from a regional perspective and a lack of feedback on action taken subsequent to COG appraisals. However, the author remained optimistic about the potential of COG's. See also Babcock, Let's Stop Romancing Regionalism, PLANNING, July 1972, at $120,121-24$ (regionalism without power to tax, regulate, and condemn bound to fail); Hoffinan, Who Shall Do the Planning? That's the Issue in Wisconsin, PLANning, Mar. 1977, at 21, 22-23 (lack of clear coustituency hampers regional government); McDowell \& Wright, The Fate of Regional Planning, PUB. MANAGEMENT, Nov. 1979, at 3 (special federal programs have tumed regional bodies into fraginented multiple planning organizations).

The council of government form of regional governance has been dealt another serious blow under the current administration's budget cuts on comprehensive planning grants that funded much regional planning. See OfFice of MANAGEMENT AND Budget, Budget of THE UnITED States Government, Fiscal Year 1982, Apr. I-L25 [hereinafter cited as 1982 Budget]. 
competing environmental, social, and economic goals that would then guide local communities in developing detailed plans for accommodating growth with minimal harm to the region's human and environmental networks.

This model would keep most land use decisionmaking at the local level, even in vulnerable areas, yet provide a mechanism for dealing with problenis whose effective resolution requires an extrajurisdictional perspective. Furthermore, the resulting data and plan would supply courts with a basis for determining whether a plaintiff had sustained the burden of estabhshing that a land use regulation did not-as required by Livermore - serve the welfare of those who felt its effects.

\section{I}

An Evaluation of Local Land Use Planning

Most land managenient has stayed at the local level for a variety of historical, praginatic, and pohtical reasons. ${ }^{14}$ Local government is more accessible to those it governs. ${ }^{15}$ Developnent happens at a particular site with and among neighbors who feel its impact for good or ill first and inost directly. When probleuns arise, people typically turn to the nearest level of government, which, because of law and tradition, has extensive experience in resolving conflicts, ${ }^{16}$ many of which involve

14. Land use regulation in the United States has always been tied to the local level. The early colonists came to America eager to throw off the constraints of a land tenure system that greatly restricted the inheritability of land, and consequently its use and alienability. By the time of the Revolution, fee simple ownership was the rule in the Colonies and owners in theory had the right to their lands from the center of the earth to the zenith of the sky to do with as they saw fit. Since neighbors were few and far between, the systein served the new nation fairly well. Its limits only became apparent as areas became densely settled and conflicts among neighboring land owners escalated. See Clawson, Historical Overview of Land-Use Planning in the United States, in Environment: A New Focus for LAND-Use Planning 23, $25-26$ (1973).

Land use problems, and the corresponding need for sonie controls, soon became perceived as a problem linked to density, that is, a city problem. Incompatible land uses were viewed as a threat to property values in cities. States responded in the early part of the 20 th century by enacting legislation, often patterned after the Standard Zoning Enabling Act, delegating responsibility for developing regulations to cities. As the loci of the problen1s, cities presumably had the greatest expertise on the problenis' roots and remedies. F. BosselmaN \& D. CALLIES, supra note 1, at 2.

The inodel state laws delegating the right to exercise the state's inherent pohice powers allowed units of local government to develop master plans and zoning regulations and to estabhish local planning bodies. The inain rationale for the state action was preservation of property values. Dirty industrial activities in the middle of residential commumities and unsightly and aesthetically offensive developments sucl as tanneries and slaughterhouses depressed the values of adjacent busimess and residential properties. Morally questionable activities such as taverns and dance halls located near schools or clurches presented another kind of problem. See S. REP. No. 197, 93d Cong., 1st Sess. 74-76 (1973).

15. Local level decisionmaking accommodates the demands for greater citizen participation and more community control fueled by the Model Cities program and sustained in the current interest in preserving neighborhoods.

16. See Jacobs, supra note 3 , at 7 . 
purely local matters. ${ }^{17}$

Local officials also have an imtimate knowledge of local problems and of the hopes that residents harbor for the future of their community. This knowledge of social and pohtical forces at work im a town can mean the difference between protracted wrangling over a land use proposal and a quick compromise. Moreover, in order to stay in office local officials must be pohtically responsive to the concerns of the local electorate, which creates a strong political support base for local control as well as cohesive opposition to the state's assuming more control. ${ }^{18}$

Another reason for the persistence of local control over land use decisionmaking may be traced to the nature of land ownership. People tend to cherish land more than other kinds of property because land symbolizes permanence. Therefore, control over land is a prominent source of pohtical power. Proximity to the seat of control also promotes security among property owners who prefer to keep a tight rein over institutions that can infringe their property rights. Even communities willing to institute strimgent land use controls to protect an economically valuable natural resource, such as a hot spring or seashore, do not want a distant government official or statewide electorate to stifle the local residents' final say over the appropriate level of development. ${ }^{19}$ Finally, political opposition to shifting land use control away from local government is not easily diffused because any such change may involve such emotionally laden issues as home rule, the mixing of races and classes, neighborhood versus integrated schools, and the entry of less stable social groups into traditional communities. ${ }^{20}$

The strong pragmatic and political reasons for keeping the bulk of land use decisionmaking at the local level cannot overshadow local government's limitations. Local government's land management systems have a poor record in three main areas: (1) protecting lands that serve vital natural or aesthetic purposes for a regional population; (2) accepting and siting development that the larger community may need badly, but which may represent net tax costs or pose social problems to the locals; and (3) controlling growth induced by magnetic developments that generate major secondary impacts. ${ }^{21}$

17. Estimates are that fewer than $10 \%$ of all land use decisions involve extrajurisdictional impacts. Councll of State Governments, State Alternatives for Planning and ManAGEMENT, A TASK FORCE REPORT 6 (1975).

18. See generally R. HEALY, supra note 2, 191-92.

19. Id. at 161-63.

20. M. LEVIN, J. ROSE \& J. SLAVET, supra note 4, at 66.

21. No. 28 Monograph, ENVT'L REP., Nov. 8, 1974, at 13, reprinted in ENVIRONMENTAL Policy Division, Congressional Research Service, library of Congress, Readings on LAND Use Policy (1975).

Other more minor criticisms are sometimes leveled at local government. First, the quality of planning efforts can vary widely from city to city because some communities are too small to 
The pursuit of local self-interest generally accounts for these shortcomings. Historically local land use regulations were developed to accommodate a fairly standard laundry list of goals: prevention of overcrowding; prounotion of peace, quiet, hight, air, and open space; and protection of public health and safety. The list has expanded fairly recently to cover unore controversial aims, including "fiscal zoning" that takes into consideration the cost of providing services, human and institutional, that are related to different kinds of development. ${ }^{22}$ This consideration, in turn, has encouraged cities to tailor regulations to accommodate "good ratables" such as clean industry that generate tax revenues and to exclude "bad ratables" that might require costly services, such as schools or relnedial social prograins. ${ }^{23}$ In addition, cooperative efforts alnong inunicipalities have also been hindered by a dearth of basic information on the limits of natural and institutional resources in the surrounding region and by the lack of a mechanism for evaluating potential regional impacts of land use decisions and working out coinpromises. ${ }^{24}$

In Associated Home Builders of the Greater Eastbay, Inc. v. City of Livermore, ${ }^{25}$ the Califorma Supreme Court acknowledged the failure

afford a competent staff. Second, influence peddling may be more of a problem at the local level. See R. HEALY, supra note 2, at 23-26.

22. See generally N. Williams, American LaNd Planning Law \& 8, at 185-86 (1974).

23. Id. §14.01.

24. See note 13 supra, which describes the limited usefulness of the present system of voluntary regional government that lacks enforcement powers, and Marks \& Taber, Prospects for Regional Planning in California, 4 PAC. L. J. 117, 119 (1973), in which the authors identify problems associated with havimg a host of single-purpose regional planning agencies, each planning according to its narrow perspective.

25. 18 Cal. 3d 582, 607, 557 P.2d 473, 487, 135 Cal. Rptr. 41,55 (1976). The suit was brought by a group of developers who sought to enjoin enforcement of an initiative ordinance that barred Livermore from issuing residential building permits until the city's educational, sewage disposal, and water supply systems met specifled standards. The city had increased its population eightfold in the 20 years following World War II. Note, A Regional Perspective of the "General Welfare," 14 SAN Diego L. REv. 1227 (1977). The huge population imflux, especially in the late 1960's and 1970's, overtaxed the water supply and sewage treatment plants and put schools on double session for 10 years. Automobile-caused air pollution reportedly exceeded federal health standards 28 days in 1972. Deutsch, Land Use Growth Controls: A Case Study of San Jose and Livermore, California, 15 SANTA Clara LaW. 1, 12-13 (1974).

The trial court granted the injunction on the grounds that the ordinance was unconstitutionally vague and that general law cities could not adopt zonimg ordinances by initiative. The supreme court reversed, finding that the ordinance did not directly infringe on nonresidents' rights to migrate to the city under the traditional test applied to land use regulations. Since the record was limited to the pleadings and stipulations, the court remanded for a determination of the ordinance's probable impact on the surrounding communities.

The decision signaled the end of a traditional deferential standard. Formerly the courts only overturned a local governing body's determination that a land use ordinance served the general welfare where such determination was "clearly and palpably wrong and the error appears beyond reasonable doubt from facts or evidence which cannot be controverted." Lockard v. City of Los Angeles, 33 Cal. 2d 453, 461, 202 P.2d 38,43 (1949) (quoting In re Miller, 162 Cal. 687, 696, 124 P. 
of California localities to adequately consider the regional impact of their land use decisions in holding that a local land use ordinance that has an impact beyond a city's boundaries must reasonably relate to the welfare of those whoin it affects. But in trying to fashion a judicial remedy for the inequities created by exclusionary practices, the court placed itself at the farthest reaclies of its competence. ${ }^{26}$ It set out a three-pronged test to determine whether a challenged ordinance reasonably relates to the regional welfare, advocating that the trial court look at (1) the probable effect and duration of the restriction, (2) the competing interests affected by the restriction, and (3) whether the ordinance, in light of its probable impact, represents a reasonable accommodation of the competing interests. ${ }^{27}$ But the courts, as the most politically isolated brancl of government with little access to data-gathering support systems, do not have the resources to assess whether a challenged land use ordinance represents a balanced package for coinplex and competing interests. ${ }^{28}$ Such an assessment could require detailed information on the existing and projected capacity of a region's educational, public works, and transportation systeins as well as its housing supply, plus information on environmental constraints, such as unstable soil or seismic hazards. The legislature is better equipped than the courts to sponsor fact-finding operations and to delegate responsibility for conducting research. Moreover, it is better able to provide a forum for an inforined debate over social, environmental, and economic tradeoffs and to determine what constitutes the relevant region according to political and economic criteria. ${ }^{29}$

427, 429 (1912)). See also Clemons v. City of Los Angeles, 36 Cal. 2d 95, 222 P.2d 439 (1950), where the court held it would defer as long as the issue was one ou which reasonable minds might differ. Id. at 98, 222. P.2d at 441.

In Livermore the court seemed to be stepping back from such wholesale deference with its admonition that "[J]udicial deference is not judicial abdication. The ordimance must have a real and substantial relation to the public welfare." 18 Cal. $3 \mathrm{~d}$ at 609,557 P.2d at 489, 135 Cal. Rptr. at 57 (emphasis in origimal).

26. See note 28 infra.

27. 18 Cal. $3 \mathrm{~d}$ at $608-09,557$ P.2d at $488-89,135$ Cal. Rptr. at 56.

28. Courts have found that land use ordinances imvolve sometimes mundane, but often complicated, issues such as future growth and development, adequacy of drainage and storm sewers, public streets, pedestrian walkways, and density of population that are "peculiarly within the legislative competence." City of Miami Beach v. Weiss, 217 So. 2d 836, 837-38 (Fla. 1969).

The proper role for the judiciary vis-á-vis the legislature has long been a subject of debate. See, e.g., Chayes, The Role of the Judge in Public Law Litigation, 89 HARv. L. Rev. 1281, 1296-98, 1313-16 (1976); Wellington, Common Law Rules and Constitutional Double Standards: Some Notes on Adjudication, 83 YALE L.J. 221 (1973); Note, Judicial Limitations on Local Growth Controls: Regional Needs as an Element of the "General Welfare," 66 CALIF. L. REv. 373, 379-80 (1978); Note, The Inadequacy of Judicial Remedies in Cases of Exclusionary Zoning, 74 MrCH. L. REv. 760 (1976).

29. Of the three branches of government-executive, legislative, and judicial-the legislature generally is considered best equipped to formulate pohicy because of its ability to implement and monitor what it determines to be a socially desirable policy through legislatively established 
The next Part of this Comment explores how the California legislature could act to expand the application of fair share allocations and cumulative impact assessment to implement the Livermore court's implied directive to achieve a more equitable distribution of development rights and responsibilities.

II

\section{INCORPORATING REgIONAL CONSIDERATIONS INTO LOCAL LAND USE REGULATION}

This Part examines two methods already used in California to incorporate regional considerations into local land use regulations-fair share allocations and cumulative impact assessinent-and suggests that these concepts be expanded beyond their present limited application to supply the kind of information that courts need to evaluate challenges to land use ordimances under the Livermore regional welfare test.

\section{A. Fair Share Allocation}

Shortly after Livermore, the Department of Housing and Community Development modified its guidelines governing the housing element of each cominunity's general plan ${ }^{30}$ to specify that provision be made for the fair share allocation of the housing needs of all economic segments of the community. ${ }^{31}$ The community was defined as the "housing market area" and the geographic area within which local interaction had resulted in an economic and social interdependence. ${ }^{32}$

Simce the fair share housing allocations determined by a regional

agencies and through the appropriations process. See Wellington, supra note 28, at 240-41. Moreover, a legislative resolution of a problem has worked its way through the political process and thus presumably has a semblance of popular support. The legislature, because of its superior fact-finding abilities, may also be better equipped to fashion affirmative remedies to counteract the effects of longstanding inequitable social conditions, such as parochial zoning and legislative neglect of low-income housing needs. See Note, The Inadequacy of Judicial Remedies in Cases of Exclusionary Zoning, 74 MicH. L. REv. 760, 789, (1976). Fimally, environmentalists, central city residents, developers, industry, and would-be residents all have a stake in a suburban community's land use regulation scheme. The desirability of giving each of their viewpoints a hearing argues for a more democratic forum than the courtroom. Id. at 779.

30. The housing element is one of nine planning eleinents mandatcd by the comprehensive general plan that every California city and county inust prepare and adopt. CAL. Gov'T CODE $\S \S 65300,65302$ (West Supp. 1981). Other required elements cover land use, circulation, conservation, open space, seismic safety, noise, scemic highways, and safety from fire and geologic hazard. Once adopted, the general plan is supposed to guide future development of the city in nraking land use decisions, especially on zoning, subdivisions, environinental controls, and the location and design of public facilities.

31. 25 CAL. AdMin. Code \& 6410(f) (May 3, 1980).

32. Id. The definition of community was subsequently dropped and the concept incorporated into $\S 6418$, which states: "For housing element purposes the community to be scrvcd by the local housing element mcludes a fair share of those market area households . . . who would hive within the local jurisdiction [wherel a variety and choice of housmg appropriate to their needs [is] 
council of government ${ }^{33}$ are supported by data reflecting regional housing needs, they furnish the courts with a balanced package determination of one aspect of the "regional welfare" on which the courts can confidently rely in assessing a Livermore-type challenge. ${ }^{34}$ Although a local government still cannot be legally coinpelled to inake.provision within its general plan for its fair share allocation of housing needs for all economic seginents of the region, ${ }^{35}$ local governments have good

available." Id. at $\$ 6418$ (May 3, 1980) Housing element requirements now have been codified. CAL. Gov't Code $\$ \S 65580-65589$ (West Supp. 1981).

The fair share allocations are calculated by either a council of government covering a region, see note 13 supra, or by the Department of Housing and Community Development for jurisdictions not served by a COG. See note 33 supra. The delegation of responsibility for determining fair share allocations has now been placed on COG's by statute. CAL. Gov'T CoDE § 65584(a) (West Supp. 1981).

The concept of fair share allocations of low-and-inoderate incone housing was clearly articulated in Southern Burlington County NAACP v. Township of Mount Laurel, 67 N.J. 151, 336 A.2d 713, appeal dismissed and cert. denied, 423 U.S. 808 (1975). There the court formulated a policy that has come to be known as the Mount Laurel doctrine, which spccifies that each developing municipality must

by its land nse regulations, presumptively make realistically possible an appropriate vari-

ety and choice of housing. More specifically, presuinptively it cannot foreclose the op-

portunity ... for low and noderate income housing and in its regulations inust

affirmatively afford that opportunity, at least to the extent of the inunicipality's fair share

of the present and prospective regional need therefor.

Ii. at 174,336 A.2d at 724 .

The case was brought as a class action by low-income minority households hiving in and around Mount Laurel, who claiuned that the township's zoning schente, which imposed relatively large minimum lot size requirentents, allocated excessive amounts of land to industrial use, and limited all residential areas to single-family homes effectively precluded the construction of lowincone housing. For an analysis of the decision and its subsequent refinement through other cases, see Comment, Exclusionary Zoning: The Mount Laurel Doctrine and the Implications of the Madison Township Case, 8 Seton Hall L. Rev. 460 (1977).

33. In making their allocations, councils of government are supposed to consider inarket demand for housing, employment opportunities, availability of suitable sites and public facilities, commuting patterns, type and tenure of housing need, and the housing needs of farmworkers. CAL. Gov't Code § 65584(a) (West Supp. 1981).

34. In Califorria a city that has provided for its fair share of housing for all economic seginents of the relevant region as evidenced by a positive review by the Department of Housing and Cominunity Developnient, see note 35 infra, can offer strong presunptive evidence that its general plan-at least as far as it relates to housing needs-has cousidered the regional welfare. Conversely, a party would be hard-pressed to meet the burden of establishing that a land use ordinance related to housing supply did not reasonably relate to the general welfare of those whom it affected where a city's housing eleinent had won a positive review froun the department. A city whose land use controls conforined to development allocations that addressed a broader range of concerns than simply housing could provide even stronger presumptive evidence that it had considered an encompassing range of factors, all of which affect the regional welfare. The city would thereby create further certainty for property owners and developers.

35. Cities and counties nust submit their proposed housing elentents and any amendments to the Department of Housing and Community Developnient for review. The department analyzes the eleinents for comphance with the statutory provisions relating to the housing elenient, CAL. Gov'T CODE $§ 65583$ (West Supp. 1981), which include the requirenent that local governinents inake provision for their fair share allocation of low-income housing as determined by the relevant COG, see note 32 supra, or the department, or, in special cases, a local government. CAL. 
reason to conform to the allocations in order to avoid expensive and protracted litigation, ${ }^{36}$ especially where local governments suspect their land use inanageinent schemes may be challenged. ${ }^{37}$ The legislature's action in providing a mechanism for determining fair share housing allocations has probably saved California from the uncertainties that have plagued other states that have applied the fair share approach to combat exclusionary zoning. ${ }^{38}$ Yet the single-focus response after Livermore leaves open the possibility of other kinds of challenges in which the court will not have the benefit of standards such as those provided by fair share housing allocations. The language of Livermore does not limit the regional perspective requirement to the housing question. The majority simply speaks of an ordinance that "reasonably relates to the welfare of those whom it significantly affects." 39 The court inay find itself in the position of trying to decide under the Livermore balancing test whether a local government has considered the regional need for open space in granting a subdivision permit or for a given standard of ambient air quality in granting a buildmg permit to a polluting factory. ${ }^{40}$

Gov'T CODE $\S \S 65584(a)-65584(b)$ (West Supp. 1981). If the community and the department cannot resolve conflicts over conformance, the community is required to include supporting data and reasons justifying its revision of its defined share of the regional housing need. Id. $\$ 65584$ (c). Moreover, the local governing body must consider the findings of the department before adopting the element. $I d . \S 65585(\mathrm{~b})$.

36. See, e.g., Note, Two Years After Mount Laurel: Zoning Ordinance Challenges and Use Variances for Multi-Family Housing, 31 RuTGERS L. REv. 994 (1979), which describes the confusion that has reigned in New Jersey since Southern Burlington County NAACP v. Township of Mount Laurel, 67 N.J. 151, 336 A.2d 713, appeal dismissed and cert denied, 423 U.S. 808 (1975), the case that articulated the "fair share" concept. See note 32 supra. Courts are still wrestling with legal problems triggered by Mount Laurel, which has not set off a rush to construct low-mcome housing in the suburbs or a noticeable exodus of poor to nonurban areas. See N. Y. Tines, Dec. 21,1980 , at $6 \mathrm{E}$, col. 3 .

37. A community that has managed to keep out polluting industrial developinent and to maintain high-income housing development through its land use planning would have good reason to suspect that its regulations inay be challenged, especially where neighboring communities are suffering financial or environmental hardship because they have accommodated less desirable development.

The possibility of legal challenge probably does not seem as immediate when housing starts are down. Local governinents are required only "to make provision for" the housing needs of all economie segments, not to actually provide housing for their fair share allocation of such need. However, the current inactivity of the low-income market offers little longterm security for coinmunities bent on preserving their exclusivity. If their general plans do not make provision for the housing needs of all economic segments of the relevant community, they are open to challenge under the Livermore test. If they do make provision for the housing needs of all economic segments, they cannot easily refuse to allow less desirable proposals to proceed, since courts regard confornance with a general plan as evidence that a proposed land use serves the general welfare.

38. See note 36 supra.

39. 18 Cal. $3 d$ at 607,557 P.2d at 487,135 Cal. Rptr. at 55.

40. An analogous challenge was raised in a recent Washington case that quoted extensively from Livermore. In that case the court overturned a city's approval of a major shopping center because the city had failed to mitigate or avoid potentially serious adverse environmental effects 
Challenges to land use ordinances based on failure to consider regional impact are most likely to arise in areas where the natural resources (air, water, stable land supply) are reaching or have reached their capacity to absorb new growth without environmental deterioration. Similarly, suits may proliferate where the public service systems (wastewater treatment, water supply, transportation) or social and economic systems (housing, schools, employinent) are in imminent danger of being overtaxed and the funds to extend such systems are not readily available. People are more likely to take lcgal action when natural or institutional resources threaten to become scarce; insiders will try to hang on to what they have while outsiders will try to get a sliare of the resources in limited supply. ${ }^{41}$ California's general plan requirements represent a significant attempt to encourage local government to consider a range of factors that affect the quality of the human environinent, including factors that absorb natural and institutional resources. But inany of the required planning elements do not supply the extralocal perspective that can become critical where regional resources show a shrinking tolerance for handling the cumulative impact of each community's developinent. ${ }^{42}$ Therefore, the legislature should expand

on areas outside the city. Save a Valuable Environment (SAVE) v. City of Bothell, 89 Wash. $2 \mathrm{~d}$ 862,576 P.2d 401 (1978). The case defines a local government's duty to consider the regional welfare not only in terms of housing - a loug recognized, high priority human need-but also in terms of environmental quality. Id. at 871,516 P.2d at 406 . Conceivably this kind of deeision could test the limits of the courts' competence even more severely than the housing issue, because "environment" is a nebulous and broad concept that eludes clear standards. See Comment, The Duty of a Municipality to Consider the Environmental Effect of Its Land Use Planning Decisions Upon the Regional Welfare: Judicial Balancing in the Absence of Interjurisdictional Planning Legislation, 25 WAYNE ST. L. Rev. 1253, 1266 (1979).

41. Past challenges to no-growth or slow-growth regulations have not necessarily been grounded in failure to relate such restrictions to the geueral welfare of the affected regiou. However, the impetus for these suits, whatever the supporting legal arguments, often has been the desire of the "outs" to secure a share of benefits in limited supply, such as clean air, space, quiet neighborhoods, uncougested streets, and good schools that the "ins" are keenly aware could be exhausted, either because the supply is finite (clean air) or because the systems could only be expanded at great cost (public transportation capacity) which might fall on the "ins" as well as any newcomers. See, e.g., Deutsch, supra note 25, at 12-13, describing the problems that beset Livermore following rapid development. Residents responded by trying to forestall further threats to their already seriously overburdened institutional and environmental systems. See Construction Industry Ass'n v. City of Petaluma, 375 F. Supp. 574 (N.D. Cal. 1974), rev'd 522 F.2d 897 (9th Cir. 1975), cert. denied, 424 U.S. 934 (1976) (clallenge to city's plan limiting new housing nmits passed because residents feared their rapidly growing city would lose its small town character); Golden v. Planning Bd., 30 N.Y.2d 359, 334 N.Y.S.2d 138, 285 N.E.2d 291, appeal dismissed, 409 U.S. 1003 (1972) (suit challenging land use ordmance restricting subdivision development because of imadequate facilities and services to handle burgeoning population at an acceptable standard).

42. The land use elenent designates the distribution and general location and extent of the uses of land within a jurisdiction. CAL. Gov'T CODE § 65302(a) (West Supp. 1981). No areawide coordination is required although one local government's population density and building intensity may lave profound effects on the environmental quality and social mix of other communities. 
the concept of fair share allocation beyond housing to encoinpass other factors in regions where the capacities of the natural and institutional resource systeins to accommodate developinent are reaching their limits.

Courts could assess whether a community's land use controls had adequately addressed the regional welfare by examining and balancing two related factors. One is the fair share allocation of negative impacts resulting from less-sought-after growth that benefits the region; the second is the localities' right to proceed with more-sought-after development that burdens regional resources. ${ }^{43}$ Cumulative impact assessment discussed in the following section suggests a inethodology for defining the capacities of regional resources. The capacities in turn can provide a basis for calculating fair share allocations of factors beyond simply housing ainong communities im a vulnerable region ${ }^{44} \mathrm{~m}$ order to inake the most efficient and equitable use of a region's existing and projected capacity to absorb growth.

\section{B. The Cumulative Impact Concept}

The fair share housing allocation concept outlines a model for providing a nore equitable accommodation of growth among communities within a region. The cunulative impact concept fleshed out in recent California Coastal Commission decisions suggests a way for re-

The conservation element does not require local government to look beyond its boundaries except on water programs, which must be coordinated with countywide, district, and city agencies. Jd. $\S 65302$ (d). The open space element refers specifically to preservation and conservation within political jurisdictions, but the parochial perspective is somewhat softened by $\$ \S 65560$ and 65561 of the California Government Code, which requires statewide coordinated planning to be developed. See J. Longtin, California Land Use Regulations \& 1.22[5] (1977). The seisinic safety element requires local governments to identify and appraise seisinic hazards, CAL. Gov'T CODE $\$$ 65302(f) (West Supp. 1981), but only within their jurisdictions. The noise element quantifies noise levels im the local environment from sources such as highways, streets, railroads, aviation, and imdustry to allow noise mitigation measures to be incorporated into the land use element. Id. \$65302(g). Again, consideration only extends to the local government's jurisdictional himits.

43. For instance, if a city's approval of a "magnet" development such as a shopping center were challenged under the Livermore test on the grounds that such a development did not serve the regional welfare, a court could consider whether the projected traffic would produce emissions that exceeded a city's allocation of the reinaining capacity of an air basin to absorb more pollutants without degradation. The court also could consider whether the expected traffic mcrease would exceed the city's fair share allocation of the existing and projected transportation capacity of the region. These allocations presuppose a regional plan, since the ability to absorb growth with minimal negative unpacts is determined by the cumulative impact of each community's actions as well as by mitigation measures, such as establishing or encouraging einployee carpool systems to cut down on auto emissions and traffic volume. This kind of mtensive planning would necessarily be expensive. Therefore, as Part III proposes, intense planning efforts should be hmited to vulnerable areas where overtaxing of natural and institutional resources is threatenimg to degrade, perhaps irretrievably, social and environmental systeins that cross local jurisdictions.

44. Factors for identifyimg vulnerable regions are identified in Part III. 
fining and expanding the fair share idea to include a broader range of developinent impacts than simply housing.

Cunnulative impact assessinent is an approach to land use manageinent that calls for evaluating a proposed developinent in terms of the existing and projected capacity of an area's natural and imstitutional resources to accommodate growth given the finite capacities of natural systems and the financial constraints on expanding institutional systeins. Unlike permit-by-permit analysis, the assessments represent projections on the conditions that would likely result if all similarly situated landowners, not just the landowner requesting approval of a proposed developinent, were allowed the same right to develop. ${ }^{45}$ The notion is often linked to "full buildout," which defines densities that would occur if development reached the limit allowed under existing land use regulations. ${ }^{46}$

The notion of cumulative impact makes a certain imtuitive sense in relation to controlling developinent effects where natural and institutional resources are scarce ${ }^{47}$ and localities' blind pursuit of self-interest could lead to imefficient decisions and possibly irreparable damage. ${ }^{48}$ But it is not easily grappled with in the real world. Potential impacts of development are difficult notions to document because impacts are a function of so many factors, soine of which can be mitigated, and de-

45. Cumulative impact assessment diverges from more traditional development permit practices in its wider frame of reference. Many projects, even large-scale developments such as shopping centers, taken by themselves may not overburden a region's resources. However, these major projects may preempt a large percentage of a region's resources so that any further development by other landowners in the same and neighboring communities with similar development rights under existing regulations would cause breakdowns in institutional systems or environmental degradation.

46. However, not all landowners may want to build to the fullest extent allowed under existing zoning. Therefore, full buildout represents the maximum, but not necessarily the most probable, impact from potential development.

47. When growth takes place slowly, communities generally can enlarge their schools, water supply, roads, and sewer systems to meet demand without major disruptions. But rapid development, such as happened in Livernnore over two decades, can cause serious institutional supply probleins.

48. In most cases, impacts of a proposed development will not transcend city or county jurisdictions and conflict resolution can be effectively handled by local government. See note 17 supra. Much permit activity deals with small-scale development proposals where the impacts are limited to immediate neighbors. Permit-by-permit analysis works well in these situations. However, as explored in Part I of this Comment, local decisionmaking is not as effective at protecting land that serves national or regional populations. It is also ineffective in promoting affirmative duties to absorb less-sought-after development and in containing the growth-inducing nature of magnet developments that set off a cham of related development. These kinds of land nse decisions can have significant effects on the regional welfare when resources grow scarce. The cumulative impact of decisions of the cities and counties along the California coast is a clear example of the first kind of failure of local decisionmaking. For a description of some of the problems on the coast, see S. ScotT, Governing California's CoAst 3-5 (1975), which details how communities vied with each other to exploit finite scenic resources amidst bountiful commercial possibilities. 
velopment trends seemingly set in motion may abruptly switch direction in a state that is not centrally planned. Furthermore, basing land use decisions on cumulative innpacts can create difficult equity and certainty problems. A rush to development might be set off if land use decisions were made according to an area's remaiming capacity to accominodate development. Under such a system, tinning instead of equity would determine the development potential of similarly situated properties, leaving property owners with hittle security about the scope of their rights. Thus, to be fair and administrable, cumulative inpact assessinent must be tied to standards and supported by the best available data.

The California Coastal Commission has been refining the concept of cumulative inpact during its tenure as the pernit-granting body for the coastal region. ${ }^{49}$ It has also encouraged the developinent of assessment methodologies to incorporate the concept of cumulative impact into the general plans of coastal communities and support its land use decisions that are challenged in the courts. These methodologies, although too expensive and detailed for most land use planning needs, could supply the inforination necessary to develop a plan to serve as a basis for allocating development rights and duties among communities where effective use of remaming resource capacity requires highly sen-

49. In response to a growing concern over threats to California's coastline, voters passed the California Coastal Initiative-Proposition 20-in 1972 (codified originally at CAL. PUB. RES. CoDE $\$ 27000$ as temporary measure; new California Coastal Act is at CAL. Pub. Res. Code $\S 30000$ (West Supp. 1981)). S. Scotr, supra note 48, at 12-15. The initiative establislied a temporary California Coastal Zone Conservation Commission and six regional commissions that were directed to prepare a coinprehensive and enforceable plan for long range conservation and management of the coast consistent with sound conservation principles and practices. The commissions are also to provide for the inamtenance, restoration, and enhancement of the quality of the coastal zone environment; the orderly, balanced utilization and preservation of the coast; and the avoidance of irreversible and irretrievable commitments of coastal resources. See generally id. at 299.

In addition, the regional commissions also were given control over the permit-granting process for the pernit area in order to lialt or modify developments contrary to the protectionist aims of the coastal initiative while the plan was being prepared. The permit area imcluded the coastal zone between the seaward limit of the state's jurisdiction and 1,000 yards inland from the mean high tide line. CaL. Pub. Res. Code $\$ \S 27104,27400$ (reenacted as $\$ 30600$ (West 1977)). The commissions were empowered to grant perinits only when a proposed development would not have any substantial adverse environmental or ecological effect and when the development conforned to the objectives of Proposition 20. Id. $\$ 27402$ (reenacted as $\$ 30604$ (West Supp. 1981)).

The legislature extended state control through passage of the California Coastal Act of 1976, id. $\$ 30002$ (West 1977), which enumerates a set of goals aimed at protecting the amenities of the coast as a valuable natural resource of enduring interest to all people of the state. Further, it requires that the 15 coastal counties and 53 coastal cities prepare local plans consistent with these policies. See Douglas, Coastal Zone Management: A New Approach in California, CoAstal Zone MANAGEMENT J., Fall, 1973, at 1. The commission must approve local plans before local governments can regain power to grant or deny development permits within their jurisdictions. CAL. PUb. Res. CoDE $\S \S 30519,30600,30604$ (b) (West $1977 \&$ Supp. 1981). 
sitive deeisionmaking. The allocations would be geared to the existing and projected capacity of a region's natural and institutional resources to accommodate growth and the affirmative duty of each community to absorb a fair share of the negative impact of development that is of benefit to the entire region. The allocations would also supply the courts faced with a Livermore-type challenge with a basis for determining if a land use regulation serves the welfare of those whon it affects.

The following subsections describe how courts have reacted to the Coastal Commission's interpretation of the cumulative impact provision of the Coastal $\mathrm{Act}^{50}$ and suggest some pitfalls $\mathrm{n} 1$ its applications. The differing judicial positions underscore the courts' concern for equity and certainty and the need for solid supporting data.

\section{Judicial Reaction to Cumulative Impact Assessment}

Section 30250 of the California Public Resources Code requires that new development on the California coast be located where "it will not have significant adverse effects, either individually or cumulatively, on coastal resources." 51 Courts have given varying interpretations to this provision. In Natural Resources Defense Council, Inc. v. California Coastal Zone Conservation Commission, ${ }^{52}$ the First District Court of Appeal affirmed the Coastal Commission's grant of building permits to fifteen property owners in a phased subdivision, which at full buildout would total 5,200 single-family residences. ${ }^{53}$ Appellants claimed that the commission should have considered not only the impact of the fifteen houses for which building permits were sought, but the cuniulative impact of the subdivision at full buildout. ${ }^{54}$ The court rejected this argument despite extensive evidence on the probable adverse impact on coastal resources that would result from completion of the subdivision..$^{55}$

However, in Coastal Southwest Development Corp. v. California Coastal Zone Conservation Commission, ${ }^{56}$ the Fourth District Court of

50. CAL. Pub. Res. Code $\$ 30250$ (West Supp. 1981).

51. Id. Section 30105.5 of the California Public Resources Code defines "cumulatively" or "cumulative effect" as the incremental effects of an individual project reviewed in connection with the effects of past projects, the effects of other current projects, and the effects of probable future projects. Id. \&30105.5.

52. 57 Cal. App. 3d 76, 129 Cal. Rptr. 57 (1st Dist. 1976).

53. Id. at 84,129 Cal. Rptr. at 62 .

54. Id. at $87,129 \mathrm{Cal}$. Rptr. at 64.

55. Id. at 84-86, 129 Cal. Rptr. at 62-64. The evidence adduced at trial slowed that at full buildout, the Sea Ranch developinent would be the largest community on the Pacific Ocean between San Francisco and Eureka, that the development liad no integrated sewage system, that transportation access, already bad, would be seriously impacted, and that erosion was a serious threat now and would get significantly worse with nore development.

56. 55 Cal. App. 3d 525, 127 Cal. Rptr. 775 (4th Dist. 1976). Similarly in Stanson v. San 
Appeal held the commission correctly considered "conditions then existing and . . . conditions that would inevitably or probably result from accelerating or setting in motion a trend productive of adverse impact upon environment and ecology." 57 The court noted that the developer's own environmental impact report indicated that the proposed nime-story motel represented a development trend in the area and that while the motel's immediate impact on physical and biotic systems would be relatively minor, the effects of such a trend would be enormous..$^{58}$

In Billings v. California Coastal Commission, ${ }^{59}$ the First District Court of Appeal added to the confusion by rejecting the Coastal Southwest reasoning. The court overturned the commission's demal of a permit to a property owner on the San Mateo coast seeking to subdivide one parcel of land into three. ${ }^{60}$ The denial had been based on several grounds, including the rationale that allowing the subdivision would set a precedent that ultimately could lead to damaging development densities. ${ }^{61}$

These not-easily-reconciled decisions suggest that defensible cuinulative assessinents will require solid supporting data to justify projections of trends being set in motion. These assessments present difficult problems because of the inevitable lack of certainty surrounding complex cause-and-effect relationships in environmental and social contexts. ${ }^{62}$ However, the next subsection describes two promising tech-

Diego Coast Regional Comm'n, 101 Cal. App. 3d 38, 161 Cal. Rptr. 392 (4th Dist. 1980), the court stated that the commission correctly considered the cumulative impact of future restaurants that might be built if a development trend were set in motion by granting the owner of a commercial building a remodeling permit to add a second-story restaurant.

57. $55 \mathrm{Cal}$. App. 3d at 537, $127 \mathrm{Cal}$. Rptr. at 781. The decision leaves unresolved one major question: At what point does a proposed development start representing a trend as opposed to an individual project to be judged on its own merits? Developers deemed to be "accelerating" a trend as opposed to setting one in motion would not receive the same treatinent accorded earlier developers-a situation that poses serious equity problems.

58. Id. at 533-34, 127 Cal. Rptr. at 779.

59. 103 Cal. App. 3d 729, 163 Cal. Rptr. 288 (1st Dist. 1980).

60. Id. at 733-34, 163 Cal. Rptr. at 290-91.

61. Following the court's narrow application of the cumulative impact provision in Billings, the legislature responded with an amendment to the Coastal Act, passed as urgency legislation, providing that "cumnlatively" or "cumulative effect" means that the incremental effects of an individual project "shall be reviewed im connection with the effect of past projects, the effects of other current projects, and the effects of probable future projects." CAL. PuB. REs. CODE $\S 30105.5$ (West Supp. 1981) (added by 1980 Cal. Stats., ch . 1087, $\S 1$ ). This development of the cumulative impact provision indicates legislative support for the Coastal Southwest interpretation that the impact of a proposed developinent should be weighed in terms of its trend-setting or growth-inducing aspects, or in other words, that the impact of a proposed development should be considered in light of the possibility of all similarly situated property owners being accorded the same treatinent.

62. See Cooper \& Vlasin, Ecological Concepts and Applications to Planning, in ENvironMENT: A NEw Focus FOR LAND-USE PLANNING 183 (1973); Croke, An Evaluation of the Impact 
niques developed under Coastal Commission sponsorship to gather data necessary to carry out review and certification of local plans consistent with the cumulative impact provision and to support its permit decisions.

\section{Data Gathering Efforts}

In the California community of Half Moon Bay, researchers looked at the capacity of three public service systenis-water supply, waste water treatment, and transportation - to handle the development densities allowed under the city's existimg land use plan. ${ }^{63}$ The researchers also examined whether the potential impact of developnient allowed under the existing plan was consistent with the Coastal Act's protectionist policies and use priorities. ${ }^{64}$ Their methodology included six steps: (1) determining the existing commitnient to developnient, (2) delineatimg areas affected by geographically specific Coastal Act policies, (3) estimatimg existing public service capacities (water supply, wastewater, highways) and developing a service capacity budget, (4) defining the type and extent of conflict between existing commitnient and Coastal Act pohicies, (5) determining alternative developnient levels and patterns consistent with those policies, and (6) impact assessment and comparative evaluation of alternatives and forniulation of the final local coastal progran1. ${ }^{65}$

The Half Moon Bay study revealed that the community land use plan provided for a population of 60,000 , but the capacity of the existing water supply system would be exceeded at just under 15,000 , waste water treatment capacity at 21,400 , and transportation capacity at 29,500 . City plans contained no provision for expanding public services to neet the densitics allowed under existing zoning. ${ }^{66}$ Moreover, the assessnient determined that the cunvulative impact of population and developnient densities would not further the policies of the Coastal Act. ${ }^{67}$ The information led Half Moon Bay to redesign its land use plan to bring it inore in line with the city's ability to handle growth ${ }^{68}$ as

of Land Use on Environmental Quality, in id. at 217; Twiss, Planning for Areas of Significant Environmental and Amenity Value, in id. at 233.

63. T. Dickert, J. Sorensen, R. Hyman, \& J. Burke, 2 Collaborative Land-Use Planning for the Coastal Zone: Half Moon Bay Case Study (1976) [hereinafter cited as Half Moon Bay CASe Study].

64. Id. at $163-95$.

65. T. Dickert \& J. Sorensen, 1 Collaborative land-Use Planning for the Coastal Zone: A Process for local Program Development 31 (1978).

66. Half Moon Bay CaSe StUdy, supra note 63, at 27.

67. Id. at $184-86$.

68. Other coastal communities such as Morro Bay also have revised their land use plans after conducting cumulative impact assessments. Like inany local governments along the coast, Morro Bay and the surrounding unincorporated areas drew their water supplies from the same 
well as with the policies of the Coastal Act. ${ }^{69}$

Researchers are also developing impact assessinent techniques to handle environmental factors. Such work on the seventy square mile watershed of Elkhorn Slough is establishing development targets based on the capacity of the hydrologic process in thirty-five subregions to accommodate development. ${ }^{70}$ Data on a number of variables, mcluding bare ground, impermeable surfaces, erosion susceptibility, and soil type, are being translated into site disturbance limits below which environmental degradation of the watershed will not occur. The targets incorporate two assumptions: (1) development should be located im areas with the lowest erosion potential and (2) sedimentation rates froin land use or watersheds should not exceed the rate of filling that has prevailed for the last fifty years. ${ }^{71}$ The information has been developed to facilitate preparation of Monterey County's local coastal program. In essence, it could yield fair share allocations for development among the less built-up subregions of a watershed that are correlated to environmental factors. ${ }^{72}$

ground water basins. In a series of permit decisions, the Coastal Commission declared that continuing the current level of development as provided for in local land use plans would create serious overdrafts and cause significant adverse affects on anadromous fishery resources, riparian and upland habitats, and coastal agriculture in violation of Coastal Act policies. The commission's stance eventually led to a permit rationing system, a ground water monitoring study, and further research on water conservation and supply alternatives, such as wastewater reclamation for Morro Bay and the surrounding communities. Boyd, Cumulative Impact Assessment-California Coastal Law, 2 COASTAL ZONE '80, at 1321, 1325-26.

The cumulative impact assessinent mandated by the Coastal Act also pushed Santa Barbara County to develop an effective mechanism for allocating water usage between city and county areas. After calculating the potential buildout allowed under existing zoning and the corresponding demand for water at such densities, the local governments came up with a downzoning proposal that aligned buildout potential more closely to the limits of the water supply. Id. at 1326-27.

69. The basic goals of the state for the coastal zone are to: (a) protect, maintain, and where feasible, enhance and restore the overall quality of the coastal zone environment and its natural and man-made resources; (b) assure orderly, balanced utilization and conservation of coastal zone resources taking into account the social and economic needs of the people of the state; (c) maximize public access to and along the coast and maximize public recreational opportunities in the coastal zone consistent with sound resource conservation principles and constitutionally proteeted rights of private property owners; (d) assure priority for coastal-dependent and coastal-related development over other development on the coast; (e) encourage state and local initiative and cooperation in preparimg procedures to implement coordimated planning and developinent for mutually beneficial uses, including educational uses, in the coastal zone. CAL. PUB. RES. CODE $\S 30001.5$ (West Supp. 1981). Many of the policies are framed in general terms and qualified by fairly ambiguous phrases, such as "where feasible" and "where appropriate" and "consistent with public safety needs." See Half MoON Bay CASE Study, supra note 63, App. A, at 81-120.

70. Dickert \& Tuttle, Elkhorn Slough Watershed: Linking the Cumulative Impacts of Watershed Development to Coastal Wetlands, Draft, preface (Oct. 31, 1980) (project funded in part under contract with Monterey County, and by grant to the University of Cahifornia, Office of Sea Grant, and by the California Resources Agency).

71. Id. at 10.

72. The natural system capacity approach being studied at Elkhorn Slough has not been tested in a permit-granting system, where the site disturbance targets possibly could become the 
The two methodologies fostered by the California Coastal Commission for assessing the potential cumulative impact of different land use regulation forns are not offered as panaceas for dealing with all land use problems that might be effectively handled by cooperative efforts among adjacent communities. The high cost of acquiring data makes such intensive efforts impractical for all but those regions where social and environmental networks are at high risk. However, the commission's experience does suggest how estimates on the capacity of natural and institutional resources can be identified and how development might be correlated among communities to make the most effective use of those capacities in these vulnerable areas.

On the California coast, the resources in scarce supply are the scenic beauty and the fragile ecosystems of the coastline. Other regions within the state may be vulnerable in the face of development pressure, or depopulation and disinvestment. The next section explores how the areas can be identified and aided through intensive research and planning similar to that carried out to protect the coastline.

\section{III}

\section{A Proposal for Aiding Vulnerable Regions}

This Comment proposes that the state identify vuhrerable regions within California according to a set of hardship indicators that will signal clusters of communities undergoing stress from radical shifts im development activity. After the initial identification, the state should secure support for intensive land use research and planning programs among the cities and counties within an identified vulnerable region. These programs would define equitable and efficient allocations of the negative and positive impacts of development among the commumities. The programs would be run by regional boards established by state statute to gather data and develop plans, giving priority to serving the regional welfare. Board members would include people elected at large from the region and people appointed from the constituent contmunities on a representational basis. The at-large inembers would represent broader interests in policy developnent, while the community

focus of litigation. The system also raises some questions about administrability. The targets might be difficult to incorporate imto standard land use classifications. For instance, developments of the same general use type, such as strawberry farms, which are widespread in the area, can have widely differing impacts depending on whether row or terrace farming techniques are used. If a more fiexible approacl is designed and mitigation measures allowed, the county will face a monitoring problem. Nor will the targets remove the necessity for hard political choices. Many subregions identified as most suitable for development, i.e, where development is least likely to create adverse cumulative impacts, are areas where development would conflict with other coastal priorities, such as maximizing public access. The site disturbance targets will not be as useful in developed areas, except where conversion from one land use category to another is a possibility. 
appointees would represent those who would be charged with implementing policies and allocations developed by the regional board.

The allocations would rely heavily on the concepts of fair share allocation and cumulative impact assessment in order to accommodate growth with minimal disruption of social and environmental networks. Local commumities would then develop land use regulations according to these allocations and the regional board's broad policy guidelines. The board would review local plans and certify those that conformed with its policies and allocations. Although the board would not have enforcement powers to require compliance, ${ }^{73}$ its actions would still have significance. ${ }^{74}$ Certification would provide courts faced with a Livermore-type challenge with strong presumptive evidence that a commumity's land use regulations have considered a broad range of competing social, economic, and environmental interests and reached a reasonable accommodation that promotes the regional welfare. ${ }^{75}$

\section{A. Identifying Vulnerable Areas}

This Comment proposes that the Califorma Legislature delegate to a state agency ${ }^{76}$ responsibility for making an initial identification of vulnerable regions by looking at seven factors to develop a vulnerability index for each city and county within the state. The factors would include percent change in population, unemployment (percent of the civilian labor force unemployed), dependency (persons less than eighteen or over sixty-four years of age as a percentage of total population), education (percent of persons twenty-five years of age or unore with less than twelfth-grade education), imcoine level (per capita mcome), crowded lousing (percent of occupied housing units with more than one person per room), and poverty (percent of families below 125 percent of the low-income level). ${ }^{77}$ These factors could then be weighted,

73. The locus of land use control should be left at the local level for political and practical reasons. See text accompanying notes 14-20 supra.

74. The regional boards can accomplish the goal of unore efficient and equitable allocation of development rights and respousibilities even willout strong enforcement powers by providing a basis for judicial review. This will allow complying cities to avoid protracted litigation. See notes 34-37 and accompanying text supra.

75. The legislature could support this result by drafting legislation that establishes a presumption that certification means the regional perspective lias been considered. This kind of presumption could be specified by language similar to that contained in the provision defining the noise element of the general plan, whiel specifies that "[t]he noise element, once adopted, shall also becoine the guideline for determining coinpliance with the state's noise insulation standards." CAL. Gov'T CODE $865302(\mathrm{~g})(6)$ (West Supp. 1981).

76. A likely agency to take on such a task is the Office of Planning and Research, which has already been delegated authority for long range planning and research and for coordinating the developinent and operation of a statewide environmental monitoring system. CAL. Gov'T CODE $\$ \S 65040$ (a), 65040(f) (West Supp. 1981).

77. The last six factors are taken from Nathan \& Adams, Understanding Central City Hard- 
with population change receiving the heaviest weight as the most probable signal of a community undergoing or about to undergo stress from development or disinvestment. ${ }^{78}$ The indicators derived from this process could then be mapped in order to highlight vulnerable regions within the state. Areas screened out by this initial identification process would contmue their usual planning arrangements, with local communities retaming the lead role in land use regulation.

\section{B. Securing Agreement for Regional Programs}

In regions identified as vulnerable, the state would enter into negotiations with the cities and counties involved to secure agreement anong them for estabhshing regional governing boards that would carry out the data-gathering and planning functions described below. The state's inain inducenrents to gain support for its proposal would be funding to carry out finely tuned research and an effective political mechanism for iniplementing regional solutions to problems whose resolution cannot be easily handled at the local level. Moreover, localities concerned over the Livermore requirenient that land use ordinances inust in some instances serve the general welfare of nonresidents inay welcome a systen that provides a clear route for avoiding problems of judicial review. ${ }^{79}$

Municipalities will want to participate if the benefits of participating outweigh the costs, a balance that will have to be adjusted to ineet the particular problems of each vulnerable region. ${ }^{80}$ Solne benefits are

ship, Political ScI. Q., Spring 1976, at 47, 49, which outlines a system for making intrametropohtan comparisons of hardship. The authors argue that where the city-to-suburb hardship ratio is high and no inetropohtan programs such as a commuter tax or special rehef to distressed areas have been developed to spread the burden, flight to the suburbs is predictable. The six factors described by Nathan and Adams would inost likely identify older cities undergoing stress but not pick up areas undergoing intense development pressure where the population may be well educated and financially stable. Hence, the addition of the population change indicator.

These indices would not be difficult to derive, since this infornation is available in the U.S. Census. The state agency could update the infornation as new data became available.

78. A typical pattern might be a cluster of high vuherabihty indices in a region covering a core city characterized by stagnant or declining industrial growth (high unemployment plus many elderly, low-income, low-education residents) surrounded by suburbs undergoing intense development pressure shown by a high percentage change in population. High vuherability indices would probably also be found in more rural areas like the Gold Country in the Sierra foothills, where rapid population shifts would be accompanied by a high dependence, low-incoine population fleeing from urban crime and high rents.

79. See notes $34 \& 37$ and accompanying text supra. An established system would also help to prevent the kind of prolonged uncertainty that has troubled New Jersey communities whose land nse plans have faced judicial review. See note 36 supra.

80. Central cities suffering from unemployment; housing shortages, and failing tax bases may be more mterested in obtaining state support. However, inducements could take a variety of forms attractive to other communities within the region. The communities might be won over by construction grants for large infrastructure investments, provision for open space acquisition funds, or low-interest loans for pollution abatennent. 
clear. For example, a locality will probably welcome the possibility of launching a highly coordinated and comprehensive assault on a regional problem such as poor public transportation or inadequate housing.

Local governments and their electorates may be aware that some problems are beyond their individual mumicipal capacities to resolve and that continued pursuit of myopic self-interest will eventually exact heavy costs from each community in a vulnerable region, because problems such as crime and air pollution refuse to stay contained within nonexclusionary cities. Moreover, communities unay be willing to take a longer range perspective if they are not also asked to support studies and planning efforts that may work agamst their short range interests. $^{81}$

Holdouts could be a problem in reaching consensus among the communities in a vuhierable area, particularly if the wealthier communities felt confident of their ability to keep problems outside the city borders. Some high-mcome communities may be willing to take on the risk of protracted litigation, on the assumption that developers will likely be discouraged. For this reason, the legislature should enact legislation allowing the affirmative vote of two-thirds of the commumities within a vulnerable area to commit all the communities to a program of regional governance, described in the next section.

\section{Implementing a Program for Vulnerable Areas}

The regional government in vulnerable areas would have four major tasks. It would (1) coordinate and oversee the research of special purpose agencies such as the air and water quahty control boards; (2) create a central regional data bank; (3) serve as a forum for working out tradeoffs between conflicting environmental, social, and economic goals for the region; and (4) create a regional plan based on the information gathered and the tradeoffs worked out. ${ }^{82}$ The plan would represent a fair share allocation of the negative impacts of development. It also would allocate development rights among the cities in a region in a way that reflected the capacity of the region's natural and institutional resources to accommodate change.

81. Short and long run interests do often collide and it is sometimes politically hazardous for local politicians to support long run, regional interests. Local leaders may be willing to transfer some traditional land use functions to the regional boards to escape the heat of these difficult decisions. See, e.g., Liebert, Another Crisis Ahead for the Coastal Commission, 11 CAL. J. 129, 130 (1980).

82. See generally Wornum, Regional Environmental Planning: A Case Study of the San Francisco Bay Area, in Land Use: Planning, Politics, and Policy $31-33$ (R. Cowart ed. 1976), in which the author argues for an umbrella agency with similar powers for the San Francisco Bay area. 


\section{Coordinating Research}

Special purpose agencies have expertise in research and data gathering in specialized areas and should logically continue their statutorily mandated programs. ${ }^{83}$ However, the regional body evaluating the big picture may be able to suggest a particular focus tailored to a local problem, thereby complementing another agency's work and increasing the usefulness of the data gathered. These agencies have a wealth of information that, with good coordination, can serve as the nucleus for more finely tuned efforts.

\section{Creating a Data Bank}

In addition to coordinating data collected by single-purpose agencies, the regional board may want to commission additional research on the weakest links in a vulnerable region's institutional or natural resource systems. Even a fragile area such as the coastline requires varying degrees of planning intensity at different locations and on different problems to yield enough information to regulate developinent on a minimal harm basis. Many systems within a vulnerable region probably will tolerate a wide range of developinent possibilities. The more general inforination available from single-purpose agencies is usually sufficient for these systems, and limited extra funding could be expended on special problems. ${ }^{84}$

Research should emphasize cumulative impact assessment with special focus on the potential impact on environmental and social net-

83. For instance, pursuant to the Federal Clean Air Act, 42 U.S.C. $§ 1857$ (c)-5 (1977), California has established an Air Resources Board, Cal. Health \& SAFETY Code $\S 39510$ (West 1979), which divides the state into air basins, id. $\$ 39001$, according to similar meteorological and geographical conditions, $i d . \S 39606$. The state board collects and coordinates data on air pollution for each basin and sets standards of ambient air quality. Id. Each district must submit a plan for ineeting the ambient air quality standard and a plan for air pollution control, both of which are reviewed by the state agency.

The state also has nine geographical water quality regions established under the authority of a State Water Resources Control Board that formulates and adopts state policy on water quality. CAL. WATER CODE $\S 1300$ (West 1971). The regional boards form and adopt water quality control plans for all areas within their regions, $i d . \$ 13240$, and consider past, present, and probable future beneficial uses of water, the environmental cliaracteristics of the hydrographic unit, and economic factors, $i d$. \& 13241 (West Supp. 1981). The developinent of these plans could also provide valuable infornation to local governments.

Some other possible sources of environmental information imclude the U.S. Forest Service, U.S. Department of Agriculture, U.S. Soil Conservation Service, U.S. Geologic Survey, local universities, state department of parks and recreation, and the Army Corps of Engineers.

84. For instance, a vulnerable region may suffer from a severe soil erosion problem that subsequently leads to water pollution problems that im turn affect water supply and land use options. This region might benefit from intensive research and experimentation with various mitigation measures and sophisticated analysis on the suitability of margimally stable lands for different uses. The same area might need only the inost general data on seismic hazards in order to plan effectively. 
works of the region assuming all property owners were allowed to develop to full buildout under the existing land use regulations of the cities and counties within a vulnerable region. ${ }^{85}$

As the experience of several coastal communities has shown, a city's land use controls may allow for developinent densities that would severely overtax the existing and projected capacity of imstitutional systems identified in general plans. ${ }^{86}$ Local communities may welcoine outside assistance, both funds and staff, to help determine if local regulations are consistent with the policies of the general plan. Readjustments can help local communities better coordinate the pace, extent, and type of growth to existing and future public service and environmental constraints.

\section{Forum for Working Out Tradeoffs}

Social and environmental aims often create land use conflicts. Job development may be welcome in high unemployment areas, but it can mean a factory that exacerbates air pollution or induces housing construction that further reduces an area's open space. Clean water programs partly or wholly subsidized by users may push up prices of goods, sometimes laying a particularly heavy burden on low-incoine groups or certain industries that employ many unskilled workers. The potential for conflict is strong, even among groups pushing different measures to benefit the environment. ${ }^{87}$

A regional governing body could serve as a foruin for inaking tradeoffs between these aims. The debate would be informed by the data provided by special purpose agencies and commissioned by the regional governinent. Debate would not be limited to slowing growth. The regional board also would have to deal with where to put developinent that communities typically try to avoid but that serves the regional welfare. The issues would be debated within the context of a regional plan developed by planning professionals hired by the board

85. Most of the information needed to complete this kind of assessment can be extractcd from correlating allowable densities under current zoning with remaining sites available for development. Population multipliers geared to differeut kinds of development then can furnish population estimates at different developmeut densities and the corresponding demand on public service systems. See Half Moon Bay CaSe STUdy, supra note 63, at 16-17. For Half Moon Bay, researchers used a population multiplier calculated on a special scliool district census that showed the average number of people per single-family dwelling unit was 3.22 , for two-family residences 2.46, and for multifamily residences 1.92 . The U.S. Census also can provide base figures for establishing multipliers. For a more detailed analysis on developing inultipliers, see R. BURCHELL \& D. Listokin, The Fiscal Impact Handbook: Estimating Local Costs and Revenues of LAND DEVELOPMENT (1978).

86. See text accompanying notes 63-72 supra.

87. See Wornum, supra note 82 , at $26-27$, for a description of several possible confrontation scenarios among simgle-purpose environmental agencies in the San Francisco Bay area. 
to translate technical information from the scientist into policies and regulations that can be implemented at the local level. ${ }^{88}$ Planners also would work closely with local governments in the region to take advantage of the particular local experience and to garner support for the final version of the plan. The plan would, as much as possible, incorporate the visions that each local community harbored for its future, but tempered by fair share allocations of an affirmative duty to accept development that benefits the region as well as allocations of land use development rights correlated to the existing and projected capacities of the region's natural and institutional systems.

\section{Developing a Plan}

The plan developed by the technicians would be debated by the board with its at-large and appointed membership. As it worked its way through the process, the plan most likely would change from the version that made the best scientific sense and represented the best spatial arrangement. But in terms of overall satisfaction to those most directly affected, the plan's allocation of development rights and responsibilities would represent the best accommodation of competing interests.

The allocations under the plan would necessarily be an outline rather than a site-specific body of rules and regulations. Local communities would draw up detailed plans that conformed to the prescriptions set out in the regional plan and implement the local version. The regional plan would fill in the gaps of local decisionmaking by framing policies that mandated a "cunulative impact" approach to development encompassing the impact of not just an individual project or one locality's land use controls, but the potential impact of each community's land use controls on the regional welfare.

Regional policies would necessarily have to be inore than broad statements or they could be subject to the criticisin often levied against general plans, which is, that they are scarcely nore than "motherhood and apple pie" statements of good intentions. The policies must be backed up with enough guidelines for local communities and their constituents to proceed with certainty, yet retain enough flexibility to accommodate local conditions. The fair share allocation inechanisin developed by the state suggests a nodel for providing flexible, but administrable standards. Supportable allocations of developinent would require detailed assessinents of existing development and its impact as

88. For a discussion of the potential and limits of the role of science in formulating planning guidelines, see Clark, Natural Science and Coastal Planning: The California Experience, Protecting the Golden Shore: Lessons from the California CoAstal Commission 177-97 (R. Healy ed. 1978). 
well as the capacity of institutional and natural systems in undeveloped areas to assimilate new development. The allocations undoubtedly would generate much debate, but it would be an informed debate conducted within relatively clear limits defined by exhaustive research.

\section{CONCLUSION}

In Associated Homebuilders of the Eastbay, Inc. v. City of Livermore, the Califorma Supreme Court announced that henceforth, local land use ordinances inust serve the welfare of those whom they affect, not just residents. This Comment suggests that state imtervention is necessary to achieve the Livermore court's objective of getting cities to accept a reasonable share of less-sought-after development of benefit to the region. State intervention is also required to provide courts a basis for determining when a party challenging an ordimance in a Livermore-type suit has met the burden of showing that the ordimance does not reasonably relate to the welfare of those it affects.

The Comment outlines a system under which the state could identify vulnerable areas undergoing stress froin rapid population shifts attributable to developinent or disinvestment where Livermore-type challenges are most likely to arise. The state would set up a voluntary systein of regional boards for these areas to coordinate intensive research efforts on the inost overburdened resources in the regions and to make fair share allocations of development rights and responsibilities among the communities. These would be correlated to the renraining capacity of natural and imstitutional systems to handle growth without deterioration. Board planners would develop the allocations from the data and then turn them over to the elected and appoimted board members for debate and compromise. Local governments would then develop detailed plans that conformed to these allocations and to board policy. Existing and projected capacity would be determined using inethodologies such as cuinulative impact assessment techinques applied on the state's highly sensitive coastal region.

Communities should be willing to transfer soine control over land use to these boards for two reasons. First, the state would concentrate funds on these vulnerable areas to subsidize expensive, finely tuned research and planning for the resolution of soine problems that cross jurisdictional lines. Second, conformance with the fair share allocations developed by the regional boards would provide local governments with strong presumptive evidence that their land use regulations are 
reasonably related to the welfare of those whom they affect as required by Livermore.

Barbara Clark*

* B.S. 1963, University of Illinois; third-year student, Boalt Hall School of Law, University of California, Berkeley. 